\title{
Problems of choosing the optimal system of executive power in the Russian
}

\author{
Vitaly Goncharov ${ }^{1, *}$, Tatiana Mikhaleva ${ }^{2}$, Grigory Vasilevich $^{2}$, Sergey Balashenko ${ }^{2}$, Jacek \\ Zalesny $^{3}$, and Artem Pukhov ${ }^{2}$ \\ ${ }^{1}$ Kuban State Agrarian University Named after I.T. Trubilin, Russia \\ ${ }^{2}$ Belarusian State University, Republic of Belarus \\ ${ }^{3}$ University of Warsaw, Republic of Poland
}

\begin{abstract}
This article is devoted to the constitutional and legal analysis of the problems of choosing the optimal system of executive power in the Russian Federation. The paper substantiates the position that the need to optimize the system of executive power in Russia is due to a number of external and internal factors that are subjective and objective in nature. The article identifies and formulates the main problems of choosing the optimal system of executive power in Russia, defines its optimal characteristics, develops and substantiates an algorithm of actions necessary in the formation and construction of an optimal system of executive power in the country. Optimization of the system of executive power in the Russian Federation will allow to fully protect the rights, freedoms and legitimate interests of citizens of the Russian Federation; strengthen the system of public authorities in the country; create conditions for the full development of society and the state.
\end{abstract}

\section{Introduction}

The Institute of Executive Power in the Russian Federation is widely analyzed in the scientific works of N.Yu. Khamaneva, O.E. Kutafin, V.V. Grib, L.Yu. Grudtsyna, V.E. Chirkin and several other authors. These works provide the basis for the analysis of the theoretical content of the executive branch in relation to its social essence. However, the share of researches that sanctify the problems of choosing the optimal system of executive power as a constitutional category is extremely small. In this regard, the main purpose of this research is a comprehensive study of the problems of choosing the optimal system of executive power in the Russian Federation, in order to expand and clarify the conceptual and categorical apparatus of the science of constitutional law in the sphere of executive power, forming a holistic concept of the optimal organization and implementation of executive power in Russia, and the subject of research is the legal framework for the formation and functioning of the executive branch in country, as well as scientific views on the problems of choosing the optimal system of executive power in the Russian Federation as a constitutional category.

\footnotetext{
*Corresponding author: niipgergo2009@mail.ru
} 


\section{Materials and Methods}

This article in the process of cognition of state-legal phenomena were used: a) General scientific methods (formal-logical, systemic, structural-functional, concrete-historical); b) General logical methods of theoretical analysis (analysis, synthesis, generalization, comparison, abstraction, analogy, modeling, etc.); c) private scientific methods (technical and legal analysis, specification, interpretation, etc.) (Zalesny, Goncharov, 2019: 129-142; Zalesny et all., 2019: 51-61; Zalesny, Goncharov, 2020a: 1-6; Goncharov et all., 2020a, 7890; Goncharov et all., 2020b, 93-106; Moros, Goncharov, 2020, 114-128; Zalesny, Goncharov, 2020b: 1-10).

\section{Results and Discussion}

The preservation of Russian statehood, its independence from foreign states and international supranational entities is possible only under the condition of structural modernization of its economy and a paradigm shift in its socio-political development. Moreover, the executive power (like any social system) needs, according to scientists, constant modernization (Sinyugin, 2011; Kiselev, 2018: 86-92), since it is part of a complex and quite dynamically developing social mechanism - state power. Moreover, these changes should make improvements to the very essence of the formation, functioning and development of the executive power system, that is, to optimize it. In this regard, philologists consider optimization as a process of creating for any phenomenon the most favorable conditions of existence and development corresponding to the surrounding reality, as well as in the form of changing the principles of formation and functioning of a phenomenon, process or system in order to improve their properties and qualities, overcoming problems that impede or impede their organization, activity and development (Ushakov, 2008).

The need for radical changes in the economic base and its social superstructure in the Russian Federation by optimizing public administration in the face of the executive power system at all its levels is due to a number of external and internal factors that are subjective and objective (Kravchenko, 2005; Cherkasov, 2009: 28-37).

The need to optimize the system of executive power is also evidenced by sociological studies conducted in 2019 (Official, 2020).

Table 1. The attitude of citizens of the Russian Federation to the possibility of optimizing the system of executive power in the country (according to the results of studies conducted in 2019).

\begin{tabular}{|c|c|c|c|}
\hline $\begin{array}{c}\text { Age categories of } \\
\text { Russian citizens }\end{array}$ & $\begin{array}{c}\text { Support the need to } \\
\text { optimize the system of } \\
\text { executive power (in \% } \\
\text { of the total number) }\end{array}$ & $\begin{array}{c}\text { Do not support the } \\
\text { need to optimize the } \\
\text { system of executive } \\
\text { power }\end{array}$ & $\begin{array}{c}\text { Indifferent (in } \\
\text { \% of the total } \\
\text { number) }\end{array}$ \\
\hline $18-30$ years old & 80 & 9 & 11 \\
\hline $31-40$ years old & 71 & 12 & 17 \\
\hline $41-50$ years old & 67 & 15 & 18 \\
\hline $51-60$ years old & 55 & 22 & 23 \\
\hline 61 years and older & 60 & 21 & 19 \\
\hline
\end{tabular}

Among the external factors that dictate the necessity and inevitability of optimizing the system of executive power in our country, the following can be distinguished.

Firstly, the growth in the modern world of the number of global problems associated with the deepening economic, environmental, demographic and other global crises of human development, the consequence of which is the increased danger that the Russian Federation, on the one hand, will not be able to cope with resolving the consequences these 
problems, and on the other hand, possessing significant natural raw materials, but a weak military potential, a huge territory and a rapidly declining population, will be the object of an encroachment, both of individual foreign states, and of various international supranational associations and organizations (for example, the UN, NATO). The global economic crisis, which has become a protracted one, dictates the need to create in Russia a sufficient tough and balanced state mechanism as a necessary condition for overcoming its consequences and ensuring the progressive development of Russian statehood (Goncharov, 2009: 9-12).

Secondly, the globalization of humanity (Gelovani, Britkov, Dubovsky, 2009), which is currently being carried out under the auspices of the United States and within the framework of the Western civilization project, will have as its logical result the emergence of a new world order, the ideological basis of which will be global neo-fascism, the essence of which will be to level not only the declared universal human values, but also with the establishment of total control over the formation and development of the basic elements and levels of the modern state-organized society (individual, the family as the primary unit of society, nation (people), society as a whole, as well as various forms of self-organization of the population) (Goncharov, 2010a: 34-38). It seems that due to the formation of global neo-fascism on the planet, states, including Russia, will lose their sovereignty and independence in determining the strategies and tactics of state and social development. For our country, this is fraught with disintegration into a number of independent states, territorial losses, as well as rapid socio-cultural, economic degradation of society, and a change in its ethnic composition.

Thirdly, attempts by modern developed states (primarily the USA, China, the European Union) to solve their internal problems facing individual states and their blocs at the expense of resources of other states with a lower level of their economic development, politically dependent on global world leaders (the so-called "export problems") (Delyagin, 2020). On the part of the United States and its satellite states, the shifting of the risks and consequences of unsuccessful socio-economic policies will be expressed in external expansion, starting from establishing control over the resources of less developed countries, capturing new markets for products, and ending with the development of new territorial living spaces and the physical destruction of the country's population, which are potential opponents of the Western civilization project of fascist (Sison, 2000: 10-15). In this regard, Russia is most vulnerable for a number of reasons (the political lack of independence of the elites, their reluctance and inability to ensure state sovereignty, independence and development of the country; lack of developed and independent institutions of public control of power; lack of state ideology, etc.). On the part of the PRC and the Islamic world, an attempt to "export problems" may result in a direct military invasion, seizure and rejection of part of the territory of the Russian Federation.

Fourthly, the consideration by world-leaders of the fact of the existence of Russia as an independent and sovereign state is an unacceptable circumstance that impedes the prospects for their development. This is compounded by the global contradictions of the Russian Federation as an independent civilization project with the main competing projects (Western, based on the establishment of global neo-fascism on the planet; Chinese, Islamic, etc.). In addition, due to the remnants of its nuclear and defense industry potential, our country is a clear and serious obstacle for the United States and its satellites on the transformation of post-industrial Western neo-imperialism to global neo-fascism.

The PRC, in turn, considers Russia as its main competitor in ideological leadership among countries that are competitors to the Western civilizational path of development. This circumstance is compounded by a demographic and resource imbalance in the development of our country and China. Recently, an attempt has been made in the West and the PRC to justify "injustice", "harmfulness" and "groundlessness" of the possession of 
such large territories by the Russian Federation with the inability and unwillingness of the ruling elite to ensure the progressive socio-economic and political development of the country and society (Brzezinski, 2020). On the part of the countries of the Islamic world, systematic attempts are being made to justify the spiritual, moral, and religious superiority of these States and their peoples over Russia and its titular nation, which within certain religious movements can serve as a sacred justification for Jihad against our country in the event of military expansion (Kadyrov, 2020).

The need to optimize the executive system in the Russian Federation is also due to a number of internal factors.

First of all, in our country, the ideological basis of Russian statehood is not fixed in the Constitution and current legislation. There is a paradoxical situation when the Basic law of the country denies the very fact of the need for constitutional legitimation and legalization of state ideology, that is, the possibility of forming and developing statehood on the basis of any ideology (since Article 13 of the Russian Constitution enshrines ideological diversity, by virtue of which no ideology can be established as a state or mandatory). Thus, despite the conservative ideology declared by the United Russia political party, it cannot be considered as a state or mandatory ideology, but is solely a program statement of this political party (Official, 2020). Thus, there is no legal basis for the formation and development of the ideological basis of Russian statehood in the country.

In addition, in the Russian Federation the public administration system is unbalanced:

a) The state apparatus is distinguished by a high level of corruption, clannishness, embezzlement (especially at the regional level) (Goncharov, Zhilin, 2010: 8-13). According to estimates by the INDEM Foundation, in 2014-2019, the growth of the level of business corruption alone in the Russian Federation amounted from 70 to 443 billion dollars per year, and the total amount of corruption exceeded 980 billion (Research, 2019). As rightly noted on 19.10.2009 President of Russia D.A. Medvedev, one of the forms of the fight against corruption is improving the technological component in public administration, improving the quality and "transparency" of public services provided, many of which should be provided electronically (Official, 2020).

b) The system of executive power is distinguished by extremely low efficiency in organizing and operating, inconsistency of costs incurred for the functioning of government bodies and their officials with the results obtained (Goncharov, 2010b: 204-211; Kiseleva, 2018: 61-69).

c) In the framework of the executive power system, there is no system of internal selfmonitoring of the efficiency and effectiveness of the functioning of various levels of government.

d) Institutions of public control of the executive power system are poorly developed, both traditional (for example, political parties) and modern, including the recently created Public Chamber of the Russian Federation. They are excluded from real participation in determining the strategy and tactics of public administration of society and the country; there is no effective mechanism for monitoring executive bodies and their officials.

e) The state and public orientation of a significant part of the ruling elite of the state (especially at the highest echelons of state and municipal administration) is doubtful.

f) A significant obstacle to the coordinated work of government bodies is the lack of consolidation in the Constitution of the country and current legislation of the system of principles of organization and operation of the executive branch in the Russian Federation. In addition, the statutory aspects of the formation and functioning of government are sometimes contradictory, not in line with the interests of the majority of the population and the prospects of maintaining state sovereignty and independence of the country, the progressive development of society. 
g) The civil servants of the executive power system are characterized by a fundamental unwillingness and inability to use positive foreign and domestic experience in optimizing the public administration system.

An important factor determining the need for speedy optimization of the executive system in the Russian Federation is the economic stagnation of the country, which has been going on for almost two decades, which is characterized by a number of signs: a) a decline in real gross domestic product and gross national income, both in absolute terms and in in per capita terms (Website, 2020a); b) low labor productivity in the country, which is not only lower than in developed foreign countries, but also in many respects inferior to labor productivity indicators in the main sectors of the economy during the USSR (Website, $2020 \mathrm{~b})$; c) a decline in the quality of reproduction and use of labor and other resources; d) the implementation of a largely unjustified artificial stagnation of the country's economy through its financial sterilization (withdrawal of financial assets from the real sector of the economy with subsequent placement either abroad or in the banking sector); e) stimulation of the economic model of an economic country based on a catch-up type of its development with a raw material orientation; f) the conditionality of political and economic decisions made in the country not by the interests of the development of society and the state, but by international communities and foreign states (under the auspices of the mythical struggle against the international economic crisis) (Website, 2020a).

Of great importance in the need for speedy optimization of the executive branch in Russia is the growth of the demographic problem in the country, which is characterized by a number of features: a) a drop in the birth rate and an increase in mortality (as a result of which there is a steady decline in the population, its aging, a drop in the number of people of reproductive age); b) the deterioration in the quality of life of most citizens (compared with developed states); c) unreasonable encouragement of migration by the authorities (as some scientists rightly note in this regard, in our country, with an extremely high level of formal and latent unemployment and a drop in gross domestic product, the absolute number of able-bodied citizens has decreased only since 2008, at that time, how the usefulness of migration has been promoted by the authorities since the beginning of democratic transformations in the country, which should be considered as the usefulness of migration processes for the authorities and their use as a medium to reduce the political activity of the population, its opposition to the policy of the authorities as a result of the ongoing changes in the ethno-cultural composition of Russian society, especially in the metropolitan area) (Website, 2020a).

It seems obvious that the implementation of the structural modernization of the Russian economy and its socio-political superstructure is possible only under the condition of optimizing the public administration system in the country, the basis of which is the executive system, and the processes of optimizing the executive system should pursue as their purposes:

1) the creation of an economic basis for the preservation of state sovereignty and independence of the country by ensuring the economic security of the Russian Federation, the formation and implementation of a model of progressive rapid development of the economy of our country (especially its real sector) (Goncharov, 2010c: 31-35; Avakyan, 2019: 18-21);

2) the restoration of controllability of the executive power system in the country by curbing the centrifugal tendencies in public administration, by tightening the struggle against separatism, clannishness and embezzlement of regional elites;

3 ) the improvement of the public administration system through the development and consolidation in the Constitution of the Russian Federation of the ideological basis of Russian statehood, which should be determined on the basis of the real objective needs of 
Russian society, the state, state-forming peoples of Russia, the prospects for their preservation and development;

4) reorganization of the state's elite in order to bring the interests and needs of the elite in line with the interests and needs of Russian society and the state, the prospects for their preservation and development (including punitive (repressive), educational measures);

5 ) the restoration of control of the executive power system by society and the state from the point of view of interests and needs of the Russian society and the state (institutions of public control of the executive branch should play an important role in this process);

6) ensuring the formation and functioning of the system of executive power on the basis of a system of certain principles of organization and activity (participation of Russian citizens in the management of public affairs; separation of powers; federalism; a combination of centralism and decentralization; legality and responsibility; electiveness; collegiality and unity of command; ethics and professionalism of state employees of the executive branch; publicity in the work of executive bodies);

7) the creation of a mechanism to support the executive power system on the part of the people, especially by developing institutions of direct democracy (for example, elections, referendum, plebiscites, territorial public self-government, etc.) (Komarova, 2014; Kalinin, 2020: 14-23; Maslovskaya, 2020: 46-52);

8) the formation of a protective mechanism of the executive branch system and its officials from negative internal and external influences (especially the influence of foreign states and international organizations), aimed at preventing the free and independent development of Russian statehood;

9) the creation of a mechanism for evaluating the effectiveness of the executive power system in Russia from the point of view of matching the results of its activities with the expenses incurred by the company on the formation and functioning of government bodies (Goncharov, 2010d: 32-37; Vasilevich et all., 2019: 85-92).

It seems that the historical fate of our country largely depends on the degree and quality of solving problems that impede the optimization of the system of state and municipal government in the Russian Federation. In this regard, we can distinguish various scenarios for the development of Russian statehood:

1) in the event that Russia refuses to optimize the system of executive power, its loss of state sovereignty and independence with subsequent collapse (loss of territorial integrity);

2) the optimization of the executive power system is not in the interests of the majority of the country's population, but of its individual classes, social groups and nations, fraught with significant risks of various social disasters (revolutions, civil wars, etc.) arising from self-reproduction;

3) the optimization of the executive power system in accordance with the interests and needs of the majority of citizens of the country will allow preserving state sovereignty and independence of the Russian Federation.

The choice of the optimal system of executive power in the Russian Federation implies the necessity and inevitability of solving a number of objective and subjective problems (Hameneva, 2003: 5-12) associated with the choice of optimal characteristics of the future system of executive power in the country.

1) Problems of choosing a strategic socio-economic and political paradigm for the development of the state (in this regard, the twenty-year experience of Russia's existence without defining clear parameters, directions and goals for its development is indicative, as a result of which the country is in constant socio-economic and political degradation).

2) Problems of the election of the ideological basis for modernization of public administration in the country. In its most simplified form, this problem appears as a choice between the capitalist and socialist ideological development platform in their numerous combinations and subspecies. 
3) Problems of determining the optimal purposes and objectives, the achievement of which should be devoted to the organization and activities of the public administration system. Among them can be identified, in particular: ensuring the implementation of the principles of organization and activities of the system of executive authorities; preservation of the state sovereignty of the Russian Federation, its independence and territorial integrity; creating conditions for the advanced sustainable development of the state and society, maximally satisfying the needs of the country's population, creating favorable conditions for the realization of rights, freedoms and legitimate interests.

4) The problems of the formation and consolidation in the Constitution of the Russian Federation and current legislation of the necessary and sufficient number of optimal principles for the organization and operation of the executive power system in the country, which will allow for the regulation of the balanced accelerated development of Russia for the long term.

5) Problems of choosing a methodology and methodology for optimizing the existing system of executive bodies within the framework of the current legislation, taking into account the most important qualitative and quantitative characteristics (in particular, the time taken to carry out individual stages of modernization of the Russian economy and public administration, priorities for optimizing the executive system, quantity and sequence of ongoing activities as part of ongoing optimization).

6) Problems of analyzing the need and prospects for using the positive experience of optimizing the executive system in Russia over the entire historical period of its existence, as well as foreign experience in optimizing the public administration system, especially of countries that have achieved a high level of human development index (Dictionary, 2020).

7) Problems of determining the need and limits of using modern technologies for optimizing the public administration system in the country, especially in terms of global modeling of phenomena and processes, modern electronic technologies (for example, the implementation of the organization and activities of executive authorities at all levels by the President of the Russian Federation called "electronic government", which should be understood as an exceptional "transparency" of the activities of the organization new executive power in the provision of public services to the population, the lack of personal contact between the consumer of services and government officials) (Dmitry, 2020).

8) The problems of forecasting and evaluating the effectiveness of constructing an optimized system of executive power for individual stages of optimization, the results of the activities of individual executive bodies and their officials (Goncharov, 2009: 9-12).

These problems of choosing the optimal model of the system of executive power must be solved in the optimal time with minimal costs and risks for the state as a whole, society and each citizen in particular.

\section{Conclusions}

Thus, the problems of choosing the optimal system of executive power in the Russian Federation suggest the choice of the necessary algorithm of actions necessary for the formation of the optimal system of executive power in the country. It seems that this algorithm should include the following stages: 1) development and consolidation in the Constitution of the Russian Federation and current legislation of the ideological basis of Russian statehood; 2) analysis of domestic and foreign experience in the organization and activities of the public administration system with the identification and evaluation of positive aspects that can be used in the process of optimizing the executive system in our country; 3) the choice of methods and technologies for constructing the optimal system of executive power in Russia; 4) selection of criteria for assessing the effectiveness and efficiency of optimization of the executive system in Russia; 5) the process of building the 
optimal system of executive power in the Russian Federation directly with the consolidation of its legal basis in the Constitution of the country and the current legislation, as well as a mechanism for monitoring and evaluating its effectiveness in organizing and operating the company, a system of internal self-control and evaluating the effectiveness of the executive branch. The first four stages are of a theoretical and applied nature (and therefore are the subject of analysis in this chapter of the study), while the last stage involves the practical implementation in the process of optimizing the system of executive power in the country.

\section{References}

1. S.A. Avakyan, Journal of the Belarusian State University. Law 3, 18-21 (2019)

2. Z. Brzezinski, The Grand chessboard (the Domination of America and its geostrategic imperatives) (2020) http://lib.ru/POLITOLOG/AMERICA/bzhezinskij.txt

3. K.V. Cherkasov, Administrative and municipal law 1, 28-37 (2009)

4. M.G. Delyagin, Export of problems: war is declared (2020) http://delyagin.ru/position/1380.html

5. Dictionary (2020) http://dictionary.finam.ru

6. Dmitry Medvedev's video blog (2020) http://blog.kremlin.ru/theme/41

7. V.A. Gelovani, V.B. Britkov, S.V. Dubovsky, The USSR and Russia in the global system (1985-2030): results of global modeling (Moscow, 2009)

8. V.V. Goncharov, Business in law 5, 9-12 (2009)

9. V.V. Goncharov, Family and housing law 1, 34-38 (2010)

10. V.V. Goncharov, S.M. Zhilin, Law and politics 1, 8-13 (2010)

11. V.V. Goncharov, Taxes and financial law 2, 204-211 (2010)

12. V.V. Goncharov, History of state and law 4, 31-35 (2010)

13. V.V. Goncharov, Taxes 1, 32-37 (2010)

14. V. Goncharov, J. Zalesny, S. Balashenko et al, Wisdom 16(3), 78-90 (2020) https://doi.org/10.24234/wisdom.v16i3.332

15. V. Goncharov, J. Zalesny, S. Balashenko, et al, Wisdom 15(2), 93-106 (2020) https://doi.org/10.24234/wisdom.v15i2.333

16. N.Yu. Hameneva, History of formation and current state of executive power in Russia ("New Legal culture", Moscow, 2003) ISBN 5-94192-006-7

17. R. Kadyrov, Representatives of 50 countries helped lead the Chechen "Jihad" against Russia (2020) http://www.interfax-religion.ru/islam/?act=news\&div=32233

18. S.A. Kalinin, Journal of the Belarusian State University. Law 3, 14-23 (2020)

19. A.S. Kiselev, Vestnik of the Saratov state law academy 2(121), 86-92 (2018)

20. T.M. Kiseleva, Journal of the Belarusian State University. Law 3, 61-69 (2018)

21. V.V. Komarova, Forms of direct democracy in Russia: a Textbook (Direct Media, Moscow, Berlin, 2014) ISBN 978-5-4460-9849-1

22. A.G. Kravchenko, Political and legal technologies for optimizing the Executive power of Russia: thesis for the degree of candidate of legal sciences (Rostov-on-don, 2005)

23. T.S. Maslovskaya, Journal of the Belarusian State University. Law 3, 46-52 (2020)

24. Y.F. Moros., V. Goncharov, Wisdom 15(2), 114-128 https://doi.org/10.24234/wisdom.v15i2.354 
25. Official website of the "United Russia" party (2020) http://www.edinros.ru

26. Research by the INDEM Foundation "Diagnostics of corruption growth 2018 (Moscow, 2019)

27. V.Yu. Sinyugin, Administrative and legal support for the reform of management activities of Executive bodies of state power: abstract of the dissertation of the doctor of law (Moscow, 2011)

28. H.M. Sison, Marxism and modernity 2-3(16-17), 10-15 (2000)

29. D.N. Ushakov, A large explanatory dictionary of the modern Russian language (Publishing house "Bucolic", "Publisher ROOSA", Vladivostok, 2008) ISBN 978-5903036-99-8

30. Website of M.G. Delyagin (2020) http://delyagin.ru

31. Website of the Ministry of finance of the Russian Federation (2020) http://www.minfin.ru

32. G.A. Vasilevich, A.A. Kashirkina, A.N. Morozov, Journal of the Belarusian State University. Law 2, 85-92 (2019)

33. J. Zalesny, V. Goncharov, Future Human Image 12, 129-142 (2019) https://doi.org/110.29202/fhi/12/12.

34. J. Zalesny, V. Goncharov, M. Savchenko, Wisdom 2(13), 51-61 (2019)

35. J. Zalesny, V. Goncharov, Journal of Legal, Ethical and Regulatory Issues 23(2), 1-6 (2020)

36. J. Zalesny, V. Goncharov, Journal of Legal, Ethical and Regulatory Issues 25(5), 1-10 (2020)

37. N.V. Zakharchenko, S.L. Hasanov, A.V. Yumashev, O.I. Admakin, S.A. Lintser, M.I. Antipina, Journal of Environmental Management and Tourism 9(3), 510-523 (2018) doi: 10.14505/jemt.v9.3(27).11 